\title{
Genetic variation in the onychophoran Plicatoperipatus jamaicensis
}

\author{
PAUL D. N. HEBERT, NEIL BILLINGTON, TERRIE L. FINSTON, MARC G. BOILEAU,* \\ MARGARET J. BEATON \& RICHARD J. BARRETTE \\ Department of Zoology, University of Guelph, Guelph, Ontario, Canada
}

\begin{abstract}
The Onychophora are a relic taxon which diverged early in the arthropod radiation and have shown little morphological differentiation for several hundred million years. Jamaica has the richest onychophoran fauna in the Caribbean and although only five species are known, they represent 7 per cent of the global fauna. The present study involved an analysis of allozyme and mtDNA diversity in Plicatoperipatus jamaicensis, an endemic species which is the commonest onychophoran on the island. The work showed that $P$. jamaicensis includes at least two different species. These taxa are largely allopatric, but co-occur at some sites without interbreeding. Allozyme and mtDNA analyses suggest their divergence in the early Pleistocene, following the Pliocene origin of the Plicatoperipatus lineage from a Macroperipatus ancestor. Allozyme variation in both species was unusually low, but sufficient to confirm that each taxon reproduces sexually. Mitochondrial DNA diversity was abundant in both species and indicated that local aggregations did not consist of kin groups. The mitochondrial genomes of both species were small enough to suggest that their organizations are unusual.
\end{abstract}

Keywords: alloyzmes, mtDNA, Onychophora, phylogeny, speciation.

\section{Introduction}

The phylum Onychophora originated at least 200million-years ago, but over this period has shown little morphological differentiation (Ghiselin, 1984). The group consists of 70 extant species which are partitioned into two families. Members of the Peripatidae are found in Africa, South/Central America, and the Malay Penninsula, while the Peripatopsidae are found in Australasia, Chile and South Africa (Ghiselin, 1984). The group was initially thought to represent a link between annelids and arthropods, but they are now regarded as a relic taxon which diverged early in the arthropod radiation (Anderson, 1973; Jamieson, 1986; Weygoldt, 1986).

Onychophorans show variable reproductive behaviour. Most members of the Peripatidae are viviparous, although a few species are ovoviviparous, while members of the Peripatopsidae are either oviparous or ovoviviparous. Despite the prevalence of strongly female-biased sex ratios in natural populations, onychophorans have been assumed to reproduce

*Present address: Section of Ecology and Systematics, Cornell University, Ithaca, NY 14850 USA. sexually. Read (1985) however, has recently shown that at least one species (Epiperipatus inthurmi) is a parthenogen. Young of viviparous species develop intra-uterinally for 3-4 months, and immediately after birth remain with their parent. Onychophorans are predators which spray liquified glue at their prey (Read \& Hughes, 1987). This method of prey capture is so expensive, that when a target is missed, the animal reingests the exudate. Onychophorans often occur naturally in small aggregations. The extended period of maternal care and their expensive mode of predation raises the possibility that such aggregations represent kin groups (Havel et al., 1989).

Due to their rarity and their tropical/subtropical distributions, there have been no prior studies on the population genetics of onychophorans. The present study involved an investigation of the genetic variation in natural populations of Plicatoperipatus jamaicensis, the sole member of a genus endemic to Jamaica (Arnett, 1961; Peck, 1975). Allozyme analysis has been employed both to verify its mode of reproduction and to examine the extent of genetic diversification among populations at four sites in northeastern Jamaica. Mitochondrial DNA (mtDNA) analysis has 
provided both an independent estimate of genetic diversification and also made it possible to ascertain if local aggregations represent kin groups.

\section{Materials and methods}

\section{Collections}

Specimens were obtained from four sites in the John Crow Mountains (Fig. 4) by searching rotten logs, treefern stumps and other debris during early March of both 1988 and 1989. Densities of onychophorans were low in mature forests with approximately one animal located every $4 \mathrm{~h}$. Densities were much higher in banana plantations, where collection rates of five animals $h^{-1}$ were typical. Although four species of onychophorans are known from these habitats, only two (P. jamaicensis, Macroperipatus insularis) were encountered in the survey. The former species was far more common ( $>1000$ specimens versus 4 ). Most individuals were frozen in liquid nitrogen immediately after collection, but those for mtDNA analysis were transported live to the laboratory.

\section{Allozymes}

Allozyme phenotypes were determined at 21 loci including: alkaline phosphatase, arginine phosphokinase (2 loci), fumarase, $\alpha$-glyceraldehyde dehydrogenase, glycerol-3-phosphate dehydrogenase, glutamate oxaloacetate transaminase, hexokinase, isocitrate dehydrogenase (2 loci), malate dehydrogenase ( 2 loci), malic enzyme, mannose phosphate isomerase, three peptidases (phenylalanine-proline, leucyl-alanine, leucyl-glycine), phosphoglucomutase, phosphoglucose isomerase, triose phosphate isomerase, and xanthine dehydrogenase. All electrophoresis was carried out on Titan III cellulose-acetate gels using standard methods (Hebert \& Beaton, 1989).

Allozyme analyses were initially carried out on all individuals from Sherwood Forest, Packi River and Beacon Hill, as well as on a subsample of 44 individuals from Reach/Ecclesdown. This preliminary survey identified two polymorphic loci at the latter site, and as a result 200 additional individuals from this site were analysed for variation at these loci.

Confirmation of the mating system employed by $P$. jamaicensis was obtained by determining the genotypes of progeny removed from the uteruses of heterozygous females. If $P$. jamaicensis reproduces asexually, then offspring should themselves be heterozygotes. Alternatively, if $P$. jamaicensis is sexual, then segregation should be noted. Interpretation of data was somewhat complicated by the fact that single females carried only
1-3 progeny which were large enough for analysis. By pooling progeny from several females, however, a sufficiently large sample was obtained to ascertain if the population was mating randomly.

\section{Mitochondrial DNA}

Mitochondrial DNA was extracted from $33 P$. jamaicensis (14 from Reach/Ecclesdown, five from Sherwood Forest, eight from Packi River, and six from Beacon Hill). Whole animals were used for mtDNA extractions, once a small piece of tissue had been removed for alloyzme studies. Specimens ranged in weight from 0.11 to $1.51 \mathrm{~g}$. The mtDNA extraction procedure of Billington \& Hebert (1988) was followed, with the following modifications: whole animals were homogenized in $15 \mathrm{ml}$ of grinding buffer, and mitochondrial pellets were re-suspended in $2 \mathrm{ml}$ of TE after centrifugation.

$P$. jamaicensis mtDNA was digested with 15 hexanucleotide sequence recognition restriction endonucleases: $A v a$ I, $B a m$ HI, $B c l$ I, $B g l$ II, Bst EII, Eco RI, Hinc II, Hind III, Nsi I, Pst I, Pvu II, Sca I, Sst I, Sty I, and $X b a$ I. Digests were conducted for at least $12 \mathrm{~h}$ and fragments were then ${ }^{32} \mathrm{P}$ end-labelled, separated by electrophoresis in 1 per cent agarose and 4 per cent acrylamide gels, and visualized by autoradiography.

Restriction sites were mapped around the $P$. jamaicensis molecule using the conventional double-digest procedure (Maniatis et al., 1982). Fragments were sized by reference to size standards of lambda-DNA (digested with Hind III and Eco RI/Hind III) and pBR322 (digested with Hpa II).

Polymorphic fragment patterns within $P$. jamaicensis were designated with a letter code $(\mathrm{A}, \mathrm{B}, \mathrm{C}$, etc.) representing their order of discovery. Thus when the restriction fragment patterns were monomorphic for a particular endonuclease, only an A pattern was designated. Endonucleases that failed to produce cuts were scored as 0 . Each individual was allotted a series of letters representing the mtDNA fragment pattern for each enzyme, producing a composite pattern for each animal. Animals with the same composite pattern were classed as members of the same mitochondrial clone (haplotype). The number of restriction sites for each clone and the number of shared sites among clones were calculated. The homology of all patterns was checked using double digests against the restriction fragment map for all monomorphic and polymorphic cut sites.

The maximum likelihood estimate of the number of nucleotide differences/site $(d)$ was calculated among $P$. jamaicensis mtDNA clones using the method of Nei et al. (1985). Values of $(d)$ were then used to construct a 
UPGMA phenogram. Nucleon diversity in each population was determined by the formula of Nei \& Tajima (1981).

\section{Results}

\section{Allozyme variation}

Eight multilocus genotypes were detected among the $P$. jamaicensis from all four sites. Two of these genotypes were detected at two or more sites, while the others were found at only one locality. Nei's (1978) unbiased genetic-identities were calculated among all genotypes as well as for $M$. insularis. A UPGMA phenogram constructed from these distances showed that the Plicatoperipatus genotypes fell into two distinct groups (Fig. 1) separated from each other by $0.15 \mathrm{D}$ (S.E. $=0.09)$. $M$. insularis was separated from the Plicatoperipatus taxa by a genetic distance of $0.33 \pm 0.14$ S.E. The two groups of Plicatoperipatus were largely allopatric, but co-occurred at Packi River without interbreeding. On

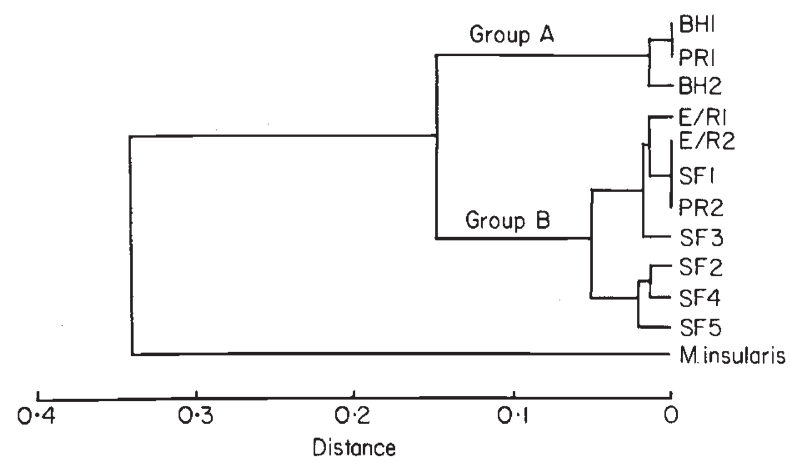

Fig. 1 Genetic distances among allozyme genotypes in $P$. jamaicensis s.l. and $M$. insularis from four sites in northeastern Jamaica. this basis, further analysis treated the groups separately.

Levels of allozyme variation were low in all taxa (Table 1). $M$. insularis was monomorphic, while members of $P$. jamaicensis group A were polymorphic at one locus, and showed average heterozygosities of 2.5 per cent. Members of group B showed variation at three loci with heterozygosities varying among sites from 0 to 1.9 per cent.

Comparison of allozyme profiles showed that members of group A were fixed for faster alleles at $\mathrm{Mpi}$ and Idh-1 than members of group B. Supernatant Got was polymorphic in group $\mathrm{A}$ but monomorphic in group $\mathrm{B}$, while the converse was true for mitochondrial Mdh and Apk-2 (Table 2). However, at all three polymorphic loci the same common allele was shared by both taxa.

Sample sizes at Sherwood Forest and Reach were large enough to permit meaningful analysis of temporal

Table 2 Frequency of the allele controlling production of the slow allozyme at five loci which showed diallelic polymorphisms in Plicatoperipatus jamaicensis

\begin{tabular}{|c|c|c|c|c|c|c|}
\hline & \multirow[b]{2}{*}{$n$} & Mdh-mit & Apk-2 & Got-S & Mpi & Idh-1 \\
\hline & & $\mathbf{S}$ & $\mathbf{S}$ & $S$ & $\mathbf{S}$ & S \\
\hline \multicolumn{7}{|l|}{ Group A } \\
\hline Beacon Hill & 5 & 1.00 & 0.00 & 0.20 & 0.00 & 0.00 \\
\hline Packi River & 1 & 1.00 & 0.00 & 0.50 & 0.00 & 0.00 \\
\hline \multicolumn{7}{|l|}{ Group B } \\
\hline Packi River & 6 & 1.00 & 0.00 & 0.00 & 1.00 & 1.00 \\
\hline Reach 88 & 244 & 0.95 & 0.00 & 0.00 & 1.00 & 1.00 \\
\hline Reach 89 & 34 & 0.97 & 0.00 & 0.00 & 1.00 & 1.00 \\
\hline Sherwood 88 & 12 & 0.96 & 0.14 & 0.00 & 1.00 & 1.00 \\
\hline Sherwood 89 & 34 & 0.93 & 0.12 & 0.00 & 1.00 & 1.00 \\
\hline
\end{tabular}

Table 1 Percentage of polymorphic loci and average heterozygosities in Macroperipatus insularis and Plicatoperipatus jamaicensis based on an analysis of 19 loci. $n=$ average sample size

\begin{tabular}{llccl}
\hline Species & Site & $n$ & $\begin{array}{l}\text { Percentage } \\
\text { polymorphic }\end{array}$ & $\begin{array}{l}\text { Percentage } \\
\text { heterozygosity }\end{array}$ \\
\hline M. insularis & Sherwood & 4 & 0.0 & 0.0 \\
P. jamaicensis A & Beacon Hill & 5 & 5.3 & 2.1 \\
& Packi River & 1 & 5.3 & 5.3 \\
P. jamaicensis B & Packi River & 6 & 0.0 & 0.0 \\
& Reach 88 & 74.8 & 5.3 & 0.5 \\
& Reach 89 & 21.4 & 5.3 & 0.3 \\
& Sherwood 88 & 10.2 & 10.5 & 1.9 \\
& Sherwood 89 & 17.6 & 15.3 & 1.9 \\
\hline
\end{tabular}


and spatial variation in genotype frequencies. $G$-tests revealed no evidence of gene-frequency shifts at either site between 1988 and 1989. Comparison of genotypic frequencies, however, at the sites following pooling of data for both years revealed significant heterogeneity in genotype frequencies at Apk $(G=36.97, P<0.001)$, but no difference at $\operatorname{Mdh}(G=0.26, P>0.10)$.

The analysis of individuals from Reach revealed 10 females that were both fecund and heterozygous at Mdh. Their embryos showed segregation with the genotypic proportions of all broods except one, which suggests that heterozygous females had mated with a male homozygous for the common allele. The exceptional brood contained an individual homozygous for the rare F-allele which is suggestive of a mating between two heterozygous individuals.

\section{Mitochondrial DNA variation}

Two (Bst EII and Sca I) of the 15 endonucleases employed failed to cut $P$. jamaicensis mtDNA, while three others ( $A v a \mathrm{I}, P s t \mathrm{I}$, and $P v u \mathrm{II}$ ) produced a single restriction site. The endonuclease Bam $\mathrm{HI}$ was polymorphic, with a single site in some individuals, and none in others. There were multiple restriction-sites for the other nine endonucleases and eight of these endonucleases were polymorphic (Table 3 ). In total, 45 restriction sites were resolved of which 27 were invariant and 18 were variable. Each individual possessed between 33 and 38 restriction sites, so that $198-228$ nucleotides representing $1.35-1.56$ per cent of the genome were surveyed. The relative positions of all sites were mapped on the molecule except for three variable Hind III sites at map positions $20-25$ which could not be located more precisely due to a lack of other restriction sites in this region (Fig. 2).

The usual size for $P$. jamaicensis mtDNA was $14,630 \pm 60 \mathrm{bp}$ (base pairs). Length inserts of approximately 420 bp occurred, however, in the three clone- 7 individuals. These length variants were each due to an insert near map position 49. The insert contained a 310 bp Hind III fragment which appeared to be a

Table 3 Fragment sizes (kilobase pairs) of Plicatoperipatus jamaicensis for those restriction endonucleases revealing polymorphisms or cutting more than once. Fragment-pattern types and length of molecule are also given for each endonuclease

\begin{tabular}{llll}
\hline Endonuclease & Pattern & Fragment size & Total length \\
\hline$B c l$ I & A & $8.16,5.08,1.35$ & 14.59 \\
& B & $7.15,5.08,1.35,1.01$ & 14.59 \\
& C & $8.16,5.08,1.03,0.38$ & 14.65 \\
Bgl II & D & $8.16,4.75,1.03,0.38,0.33$ & 14.65 \\
& A & $7.90,5.49,1.27$ & 14.66 \\
Eco RI & B & $6.86,6.28,1.57$ & 14.71 \\
& A & $4.80,2.58,2.40,1.74,1.61,0.78,0.68$ & 14.59 \\
Hinc II & B & $4.80,2.58,2.53,2.40,1.61,0.68$ & 14.60 \\
& A & $9.78,4.85$ & 14.63 \\
Hind III & B & $6.87,4.85,2.92$ & 14.64 \\
& A & $4.98,2.65,2.63,2.05,1.46,0.42,0.35$ & 14.54 \\
& B & $4.98,3.00,2.63,2.05,1.46,0.42$ & 14.54 \\
Nsi I & C & $4.98,3.10,2.65,1.46,0.81,0.63,0.59,0.35$ & 14.57 \\
Sst I & D & $4.98,3.10,2.65,1.46,0.81,0.63,0.35,0.31,0.28$ & 14.57 \\
& A & $8.26,6.45$ & 14.72 \\
Sty I & A & $8.36,3.64,2.67$ & 14.67 \\
& B & $8.36,6.31$ & 14.67 \\
Xba I & A & $9.80,4.80$ & 14.60 \\
& B & $8.68,4.80,1.22$ & 14.70 \\
& C & $8.68,6.00$ & 14.68
\end{tabular}


Table 4 Plicatoperipatus jamaicensis mtDNA clones recognized using nine polymorphic endonucleases

\begin{tabular}{llllllllll}
\hline Clone & Bam HI & $B c l$ I & Bgl II & Eco RI & Hinc II & Hind III & Sst I & Sty I & $X b a$ I \\
\hline 1 & 0 & A & A & A & A & A & A & A & A \\
2 & A & B & A & A & A & A & A & A & A \\
3 & A & B & A & A & B & A & A & A & A \\
4 & A & B & A & A & A & A & A & A & A \\
5 & 0 & B & A & A & A & A & B & A & A \\
6 & 0 & B & A & A & B & A & B & A & B \\
$7 *$ & 0 & B & A & A & B & A & A & A & B \\
8 & 0 & B & A & A & A & B & B & A & B \\
9 & 0 & C & B & B & B & C & A & B & C \\
10 & 0 & D & B & B & B & C & A & B & C \\
11 & 0 & C & B & B & B & D & A & C & C \\
\hline
\end{tabular}

*These animals have a 420 bp insert at map position 49 which includes an additional $310 \mathrm{bp}$ Hind-III fragment.
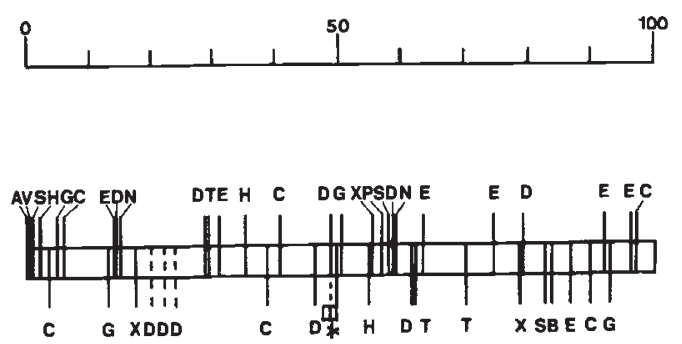
Haplotype
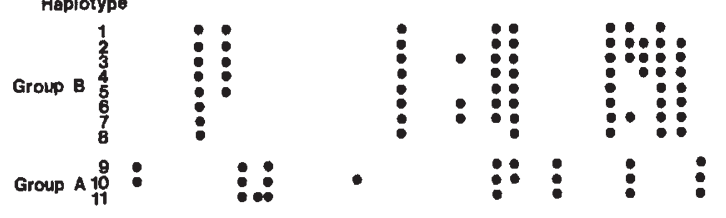

Fig. 2 Restriction site map for mtDNA in Plicatoperipatus jamaicensis s.l. Endonucleases: $\mathrm{A}=A v a \mathrm{I}, \mathrm{B}=B a m \mathrm{HI}$, $\mathrm{C}=B c l \mathrm{I}, \mathrm{D}=H$ ind $\mathrm{III}, \mathrm{E}=E c o$ RI, $\mathrm{G}=B g l \mathrm{II}, \mathrm{H}=$ Hind $\mathrm{II}$, $\mathrm{N}=N s i \mathrm{I}, \mathrm{P}=$ Pst $\mathrm{I}, \mathrm{S}=$ Sst I, T $=$ Sty I, $\mathrm{V}=P v u \mathrm{II}, \mathrm{X}=X b a \mathrm{I}$. The molecule has been depicted linearly opened at a conserved $A v a$ I site. Invariant sites are shown above the line, while variable sites are shown below the line, with filled circles representing their presence in a particular haplotype. A map scale of 0-100 arbitrary units is employed. The location of a 420 bp length insert is indicated by ${ }^{*}$. The relative positions of three Hind III sites (map position 20-25) are uncertain (dotted lines).

partial repeat of the adjacent $350 \mathrm{bp}$ Hind II fragment (Fig. 2).

Eleven mtDNA clones were resolved based on the composite patterns obtained from the polymorphic endonucleases (Table 4). These 11 haplotypes were observed among 33 individuals from the four localities. Sequence-divergence comparisons indicated that there were two distinct groups of genotypes (Fig. 3). More- over, there was a clear correspondence between allozymic and mtDNA divergence. Thus, the sole member of mtDNA group-A from Packi River was also the sole member of allozyme group-A from this site.

Further analysis of haplotype diversity patterns treated the two groups separately (Fig. 4). Group-B haplotypes were observed at three sites. Animals at Sherwood Forest consisted of a single clone, while seven different clones were detected at Reach/Ecclesdown. Four haplotypes were detected among six animals sampled in 1988 ( $2 \mathrm{cl} 2,1 \mathrm{cl} \mathrm{3,1} \mathrm{cl} 4$, and $2 \mathrm{cl}$ 7), while in 1989, five clones ( $2 \mathrm{cl} 4,3 \mathrm{cl} \mathrm{5,1} \mathrm{cl} \mathrm{6,1} \mathrm{cl} \mathrm{7,}$ and $1 \mathrm{cl} 8$ ) were represented among eight individuals. The Packi River site contained three haplotypes which it shared with Sherwood Forest or Reach. Three group A haplotypes were detected at Beacon Hill, with the dominant group-A haplotype also being found at Packi River. Nucleon diversity values (Nei \& Tajima, 1981) for group-A haplotypes were 0.00 and 0.699 at Beacon

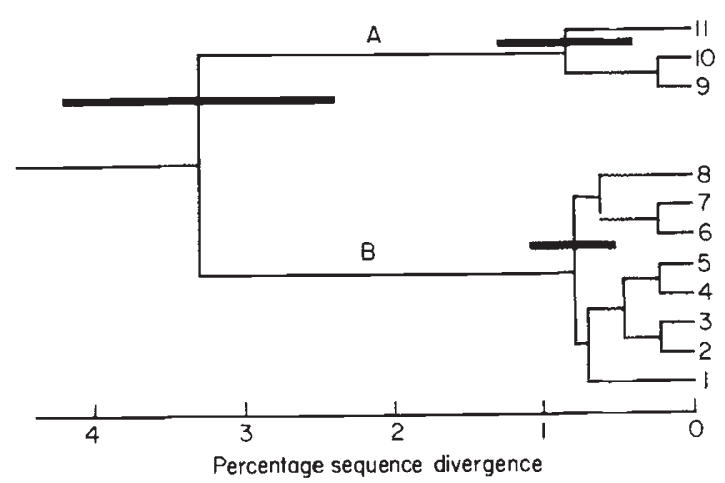

Fig. 3 UPGMA-derived dendrogram of $11 \mathrm{mtDNA}$ haplotypes observed in Plicatoperipatus jamaicensis s.l. Error bars on major nodes represent \pm 1 S.E. 


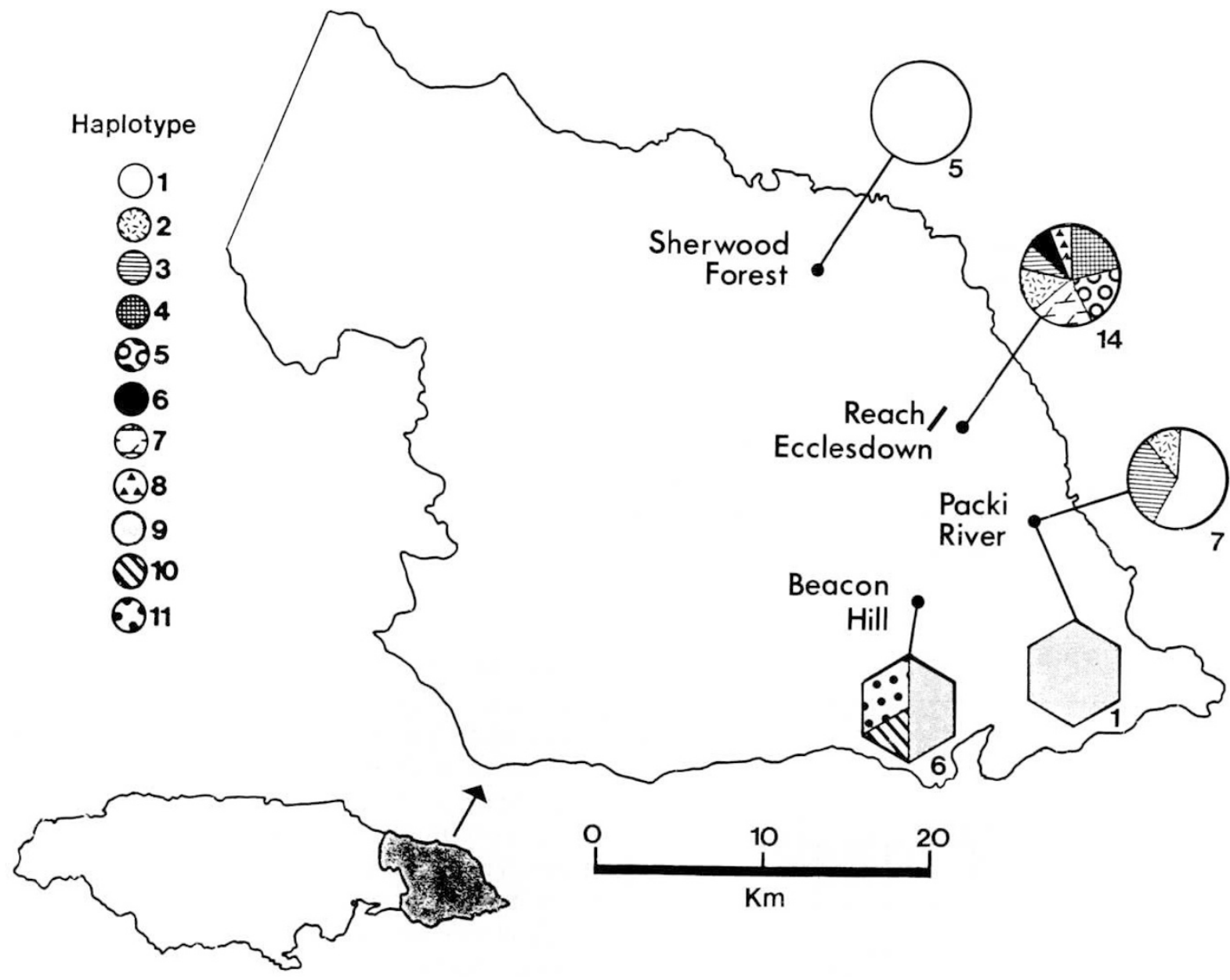

Fig. 4 Haplotype diversity in mtDNA from $P$. jamaicensis s.l. at four sites in northeastern Jamaica. Group A (hexagons), Group $\mathrm{B}$ (circles). Numbers indicate sample size.

Hill, whereas values for group-B haplotypes were 0.00 at Sherwood Forest, 0.667 at Packi River, and 0.891 at Reach.

Multiple individuals were analysed at two sites from three different aggregations. Five individuals collected together at Beacon Hill possessed three haplotypes (2 cl 9, $1 \mathrm{cl} 10,2 \mathrm{cl} 11)$. At Packi River, two aggregates were analysed. The first included three haplotypes $(1$

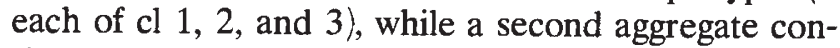
sisted of two haplotypes ( $3 \mathrm{cl} 1$, and $1 \mathrm{cl} \mathrm{3}$ ). One of these clone- 1 individuals was distinct from the others in that it showed a small $(100 \mathrm{bp})$ length increase.

\section{Discussion}

The island of Jamaica first formed at least 60-millionyears ago, but subsidence during the Eocene resulted in its submergence (Buskirk, 1985). The island reemerged about 20-million-years ago and reached its current size over the next 10-million-years. Soon after its emergence, Jamaica was colonized by Central American elements which island hopped along the Nicaraguan rise (Buskirk, 1985).

The onychophoran fauna of Jamaica includes five species belonging to five genera. Two of the genera are endemic, but the others (Epiperipatus, Macroperipatus, Peripatus) are broadly distributed in Central and South America, as well as the Caribbean. Their presence suggests the colonization of Jamaica on at least three occasions over the past 20 million years and the subsequent evolution of the endemic genera Plicatoperipatus and Speleoperipatus. There have, however, been no attempts to ascertain phylogenetic relationships among members of the Jamaican fauna.

The present study focused on $P$. jamaicensis, the sole recognized species in this genus, and the most widely distributed onychophoran in Jamaica. Both mtDNA and allozyme analysis revealed the presence of two genetically divergent groups in northeastern Jamaica. Evidence that these groups represented two 
Table 5 Variation in mitochondrial genome sizes among invertebrates

\begin{tabular}{|c|c|c|}
\hline Taxon & Size (kbp) & Reference \\
\hline $\begin{array}{l}\text { Platyhelminthes } \\
\text { Fasciola hepatica }\end{array}$ & 14.5 & Garey \& Wolstenhome (1989) \\
\hline $\begin{array}{l}\text { Nematoda } \\
\text { Caernorhabditis elegans } \\
\text { Ascaris suum } \\
\text { Meloidogyne spp. } \\
\text { Romanomeris culicivorax }\end{array}$ & $\begin{array}{l}13.8 \\
14.3 \\
20-23 \\
26-32\end{array}$ & Hyman (1988) \\
\hline $\begin{array}{l}\text { Mollusca } \\
\text { Cepaea nemoralis } \\
\text { Mytilus spp. } \\
\text { Placopecten magellanicus }\end{array}$ & $\begin{array}{l}15.7 \\
17.1-20.7 \\
32.1-39.3\end{array}$ & $\begin{array}{l}\text { Stine (1989) } \\
\text { Edwards \& Skibinski (1987) } \\
\text { Snyder et al. (1987) }\end{array}$ \\
\hline $\begin{array}{l}\text { Echinodermata } \\
\text { Strongylocentrus spp. } \\
\text { Lytechinus pictus }\end{array}$ & $\begin{array}{l}15.7 \\
15.7\end{array}$ & Brown (1983) \\
\hline $\begin{array}{l}\text { Onychophora } \\
\text { Plicatoperipatus jamaicensis } \\
\text { Macroperipatus torquatus } \\
\text { M. insularus }\end{array}$ & $\begin{array}{l}14.6 \\
15.2 \\
16.2\end{array}$ & $\begin{array}{l}\text { Present study } \\
\text { N. Billington (unpublished data) }\end{array}$ \\
\hline $\begin{array}{l}\text { Arthropoda } \\
\text { Chelicerata } \\
\text { Limulus polyphemus }\end{array}$ & $14.5-16.0$ & Saunders et al.(1986) \\
\hline $\begin{array}{l}\text { Crustacea } \\
\text { Artemia spp. } \\
\text { Daphnia pulex }\end{array}$ & $\begin{array}{l}15.0 \\
15.4\end{array}$ & $\begin{array}{l}\text { Marco et al. (1989) } \\
\text { Stanton (1988) }\end{array}$ \\
\hline $\begin{array}{l}\text { Insecta } \\
\text { Caledia captiva } \\
\text { Drosophila spp. } \\
\text { Gryllus spp. } \\
\text { Cochliomyia hominivorax } \\
\text { Schizaphis graminum }\end{array}$ & $\begin{array}{l}15.0 \\
15.7-19.5 \\
15.8-16.4 \\
16.0 \\
18.0\end{array}$ & $\begin{array}{l}\text { Marchant (1988) } \\
\text { Fauron \& Wolstenholme (1976) } \\
\text { Harrison } \text { et al. }(1985) \\
\text { Roehrdanz }(1989) \\
\text { Powers } \text { et al. }(1989)\end{array}$ \\
\hline
\end{tabular}

species was strengthened by their co-occurrence without interbreeding at Packi River. The two taxa show an allozyme divergence of $0.15 \mathrm{D}$ which corresponds to a divergence time of 2.85 ( \pm 1.71 ) myrbp employing the most generally accepted calibration of the allozymic clock which assumes that one unit of $D$ is equivalent to 19-million-years (Carlson et al., 1978; Vawter et al., 1980). An independent estimate of their divergence time can be obtained from the mitochondrial-sequence comparison. Nucleotide substitutions in the mitochondrial genome occur at a rate of approximately 2 per cent million years ${ }^{-1}$ (Brown 1983; DeSalle et al., 1987; Moritz et al., 1987; Caccone et al., 1988). Based on their $3.30 \pm 0.23$ per cent divergence, the two Plicatoperipatus species last shared a common ancestor 1.65 ( \pm 0.45 S.D.) myrbp. The joint results of the allozyme and mitochondrial analyses suggest that the taxa diverged in the early Pleistocene. As the type locality for P. jamaicensis is Beacon Hill (Arnett, 1961), group-A most likely represents the nominate species, while group-B is an undescribed taxon. Because the present survey examined specimens from less than 10 per cent of Jamaica's surface area, other species may remain unrecognized. The allozyme data revealed a genetic distance of 0.33 between Plicatoperipatus and Macroperipatus, which suggests their divergence from a common ancestor some 6.27 ( \pm 2.66 S.D.) myrbp.

Levels of allozyme variation were lower in both Plicatoperipatus species than in most other invertebrate groups (Nevo et al., 1984). M. insularis appeared to lack variation completely, suggesting that onchophorans may generally share with groups, such as aphids and hymenopterans, a lack of variation. The presence of some allozyme variation, coupled with 
joint maternal/offspring analysis, made it possible to verify that both species of Plicatoperipatus reproduce sexually. The paucity of variation, however, made it impossible to ascertain if aggregations represented kin groups. Mitochondrial DNA analysis revealed substantial diversity, with three haplotypes in group-A and nine in group-B. Sequence divergence among haplotypes in each group was less than 1 per cent, a value similar to that noted in other intraspecific studies (DeSalle et al., 1986; Crease et al., 1989). Analyses at both Beacon Hill and Ecclesdown showed that aggregations included two or more haplotypes, indicating that they were not mother-offspring associations.

The mitochondrial genome of most $P$. jamaicensis s.l. was approximately $14.6 \mathrm{~kb}$ in length, one of the smallest yet observed. No vertebrate is known to possess a mitochondrial genome smaller than $15.5 \mathrm{~kb}$ (Brown, 1983) and those of most invertebrates are larger than $15.0 \mathrm{~kb}$ (Table 5). Smaller genomes have been detected in a trematode ( $14.5 \mathrm{~kb})$ and two nematodes $(13.8,14.3 \mathrm{~kb})$, but their miniaturization has involved an alteration in genome structure. Thus the trematode has a unique tRNA structure (Hyman, 1988), while the nematodes show both loss of the ATPase 8 gene and tRNA modification (Garey \& Wolstenholme, 1989). Further study is required to ascertain how $P$. jamaicensis has accomplished reduction of its genome size. The current study revealed one haplotype which contained a $420 \mathrm{bp}$ insert, which appeared to have arisen as a result of tandem duplication. Prior studies have shown that length variation is not rare among invertebrates (Moritz et al., 1987) and that inserts typically occur in the $\mathrm{A}+\mathrm{T}$ rich region.

\section{Acknowledgments}

We would like to thank J. Havel, C. Wilson, M. Mallott, P. Gajda and M. Murdoch, as well as the people of Reach/Ecclesdown, Beacon Hill and Packi River, Jamaica for help in the collection of specimens. The research was funded, in part, by a grant to P.D.N.H. from the Natural Sciences and Engineering Research Council of Canada.

\section{References}

ANDERson, D. T. 1973. Embryology and Phylogeny in Annelids and Arthropods. Pergamon Press, Oxford.

ARNETT, R. H. 1961. The Onychophora of Jamaica. Ent. News, 72, 213-221.

BILLINGTON, N. AND HEBERT, P. D. N. 1988. Mitochondrial DNA variation in Great Lakes walleye (Stizostedion vitreum) populations. Can. J. Fish. Aquat. Sci., 45, 643-654.
BROWN, w. M. 1983. Evolution of animal mitochondrial DNA. In: Nei, M. and Koehn, R. K. (eds), Evolution of Genes and Proteins, Sinauer, Sunderland, MA.

BUSKIRK, R. E. 1985. Zoogeographic patterns and tectonic history of Jamaica and the northern Caribbean. J. Biogeogr., 12, 445-461.

CACCONE, A., AMATO, G. D. AND POWELL, J. R. 1988. Rates and patterns of scnDNA and mtDNA divergence within the Drosophila melanogaster subgroup. Genetics, 118, 671-683.

CARLSON, J. W., WILSON, A. C. AND MAXSON, R. D. 1978. Do albumin clocks run on time? A reply. Science, 200, 1183-1185.

CREASE, T. J., STANTON, D. J. AND hEBERT, P. D. N. 1989. Polyphyletic origins of asexuality in Daphnia pulex. II. Mitochondrial-DNA variation. Evolution, 43, 1016-1026.

DESALLE, R., FREEDMAN, T., PRAGER, E. M. AND WILSON, A. C. 1987. Tempo and mode of sequence evolution in mitochondrial DNA of Hawaiian Drosophila. J. Mol. Evol., 26, 157-164.

DESALLE, R., GIDDINGS, L. v. AND KANESHIOR, K. Y. 1986. Mitochondrial DNA variability in natural populations of Hawaiian Drosophila. II. Genetic and phylogenetic relationships of natural populations of $D$. silvestris and $D$. heteroneura. Heredity, 56, 87-96.

EDWARDS, C. A. AND SKIBINSKI, D. O. F. 1987. Genetic variation of mitochondrial DNA in mussel (Mytilus edulis and $M$. galloprovincialis) populations from South West England and South Wales. Mar. Biol., 94, 547-556.

FAURON, C. M.-R. AND WOLSTENHOLME, D. R. 1976. Structural heterogeneity of mitochondrial DNA molecules within the genus Drosophila. Proc. Natl. Acad. Sci., USA, 73, 3623-3627.

GAREY, J. R. AND WOLSTENHOLME, D. R. 1989. Platyhelminth mitochondrial DNA: evidence for early evolutionary origin of a tRNA ${ }^{\text {ser }}$ AGN that contains a dihydrouridine arm replacement loop, and of serine-specifying AGA and AGG codons. J. Mol. Evol., 28, 374-387.

GHISELIN, M. T. 1984. Peripatus as a living fossil. In: Eldredge, N. and Stanley, S. M. (eds), Living Fossils, Springer-Verlag, New York.

HARRISON, R. G., RAND, D. M. AND WHEELER, w. C. 1985. Mitochondrial DNA size variation within individual crickets. Science, 228, 1446-1448.

HAVEL, J. E., WILSON, C. C. AND HEBERT, P. D. N. 1989. Parental investment and sex allocation in a viviparous onychophoran. Oikos, 56, 224-232.

HEBERT, P. D. N. AND BEATON, M. J. 1989. Methodologies for Allozyme Analysis using Cellulose Acetate Electrophoresis. Helena Laboratories, Beaumont, TX.

HYMAN, B. C. 1988. Nematode mitochondrial DNA: anomalies and applications. J. Nematol, 20, 523-531.

JAMIESON, B. G. M. 1986. Onychophoran - euclitellate relationships: evidence from spermatozoal ultrastructure. Zool. Scrip., 15, 141-155.

MANIATIS, T., FRITISCH, E. F. AND SAMBROOK, J. 1982. Molecular Cloning: A Laboratory Manual. Cold Spring Harbor Laboratory, New York. 
MARCHANT, A. D. 1988. Apparent introgression of mitochondrial DNA across a narrow land zone in the Caledia captiva species-complex. Heredity, 60, 39-46.

MARCO, R., BATUECAS, B., MORATILLA, C., DIEZ-SEBASTIAN, J., GOMEZRIOJA, R., DIAZ-OTERO, F., VALENCIA, A., CALLEJA, M., VALVERDE, J. R. AND GARESSE, R. 1989. Artemia mitochondrial DNA. In: Warner, A. W., Bradshaw, J. C. and MacRae, T. H. (eds), Cell and Molecular Biology of Artemia Development. Plenum, New York, pp. 329-342.

MORITZ, C., DOWLING, T. E. AND BROWN, w. M. 1987. Evolution of animal mitochondrial DNA: relevance for population biology and systematics. Ann. Rev. Ecol. Syst., 18, 269-292.

NEI, M. 1978. Estimation of average heterozygosity and genetic distance from a small number of individuals. Genetics, 89, 583-590.

NEI, M., STEPHENS, J. C. AND SAITOU, N. 1985. Methods for computing the standard errors of branching points in an evolutionary tree and their application to molecular data from humans and apes. Mol. Biol. Evol., 2, 66-85.

NEI, M. AND TAJIMA, F. 1981. DNA polymorphism detectable by restriction endonucleases. Genetics, 97, 145-163.

NEVO, E., BELIES, A. AND BEN-SHLOMO, R. 1984. The evolutionary significance of genetic diversity: ecological, demographic, and life history correlates. In: Mani, G. S. (ed.), Evolutionary Dynamics of Genetic Diversity. Springer-Verlag, Berlin, pp. 13-213.

PECK, S. B. 1975. A review of the New World Onychophora with the description of a new cavernicolous genus and species from Jamaica. Psyche, 82, 341-358.

POWERS, T. O., JENSEN, S. G., KINDLER, S. D., STRYKER, C. J. AND SANDALL, L. J. 1989. Mitochondrial DNA divergence among greenbug (Homoptera: Aphididae) biotypes. Ann.
Entomol. Soc. Am., 82, 298-302.

READ, V. M. ST. J. 1985. The ecology of Macroperipatus torquatus (Kennel) with special reference to feeding and a taxonomic review. Ph.D. thesis, University College of North Wales, Bangor.

READ, v. M. ST. J. AND HUGHES, R. N. 1987. Feeding behaviour and prey choice in Macroperipatus torquatus (Onychophora). Proc. R. Soc. Lond. B., 230, 483-506.

ROEHRDANZ, R. L. 1989. Intraspecific genetic variability in mitochondrial DNA of the screwworm fly (Cochliomyia hominivorax). Biochem. Genet., 27, 551-559.

SAUNDERS, N. C., KESSLER, L. G. AND AVISE, J. C. 1986. Genetic variation and geographic differentiation in mitochondrial DNA of the horseshoe crab, Limulus polyphemus. Genetics, 112, 613-627.

SNYDER, M., FRASER, A. R., LAROCHE, J., GARTNER-KEPKAY, K. E. AND zouros, E. 1987. Atypical mitochondrial DNA from the deep-sea scallop Placopecten magellanicus. Proc. Natl. Acad. Sci., U.S.A., 84, 7595-7599.

STANTON, D. J. 1988. Evolution of asexuality in Daphnia pulex: implications of mitochondrial DNA analysis. Ph.D. thesis, University of Windsor.

STINE, o. C. 1989. Cepaea nemoralis from Lexington, Virginia: the isolation and characterization of their mitochondrial DNA, the implications for their origin and climatic selection. Malacologia, 30, 305-315.

VAWTER, A. T., ROSENBLATT, R. AND GORMAN, G. C. 1980. Genetic divergence among fishes of the eastern Pacific and the Caribbean: support for the molecular clock. Evolution, 34, 705-711.

WEYGOLDT, P. 1986. Arthropod interrelationships - the phylogenetic-systematic approach. Zeit. fur. Zool. System. und Evolution, 24, 19-35. 